\title{
Dental Abnormalities and Oral Pathology of the Pataud 1 Upper Paleolithic Human*
}

\section{Anomalies dentaires et pathologie orale du sujet Pataud 1 daté du Paléolithique supérieur}

\author{
S. Villotte $\cdot$ A.R. Ogden $\cdot$ E. Trinkaus \\ Received: 26 March 2018; Accepted: 25 July 2018 \\ C Société d'Anthropologie de Paris et Lavoisier SAS 2018
}

\begin{abstract}
We have re-evaluated the dental abnormalities and oral pathology evident on the Mid-Upper Paleolithic Pataud 1 skeleton, including additional remains recently excavated for this individual, in an effort to expand current knowledge of Pleistocene human paleopathology, in light of current clinical and paleopathological assessments of oral variation and diseases. The young adult female Pataud 1 presents an impacted right $\mathrm{M}^{3}$, widespread periodontitis, large retromolar voids, double right maxillary supernumerary (paramolar) teeth, and new bone deposition on the medial mandibular rami and posterior maxillae. The Pataud 1 remains thus join a substantial sample of Pleistocene humans with congenital/developmental abnormalities, some of which (as in Pataud 1) consequently resulted in secondary abnormalities. $\mathrm{M}^{3}$ impaction and supernumerary teeth are known in a couple of other Mid-Upper Paleolithic individuals, and mild to moderate periodontal disease appears to have been widespread. However, such marked resorption of the alveolar margin in a young adult is unusual, and the secondary inflammation (possibly septicemia) leading to new bone deposition is otherwise unknown in the sample and may have led to her death.
\end{abstract}

S. Villotte $(\bowtie)$

CNRS, UMR 5199 PACEA, bât. B8,

allée Geoffroy-Saint-Hilaire,

université de Bordeaux, CS 50023, 33615 Pessac cedex, France

e-mail : sebastien.villotte@u-bordeaux.fr

A.R. Ogden

Biological Anthropology Research Centre,

Archaeological Sciences,

University of Bradford, BD7 1DP, United Kingdom

E. Trinkaus

Department of Anthropology, Washington University,

Saint-Louis MO 63130, United States

* Grant Sponsorship: Leakey Foundation, Agence Nationale de la Recherche (ANR GRAVETT'OS [ANR-15-CE33-0004]).
Keywords Dental impaction · Supernumerary tooth · Periodontitis $\cdot$ Septicemia

Résumé Les anomalies dentaires et la pathologie orale du squelette Pataud 1, datant du Paléolithique supérieur moyen et pour lequel de nouveaux éléments osseux et dentaires ont été récemment découverts, sont réévaluées à la lumière des avancées cliniques et paléopathologiques afin d'accroître notre connaissance sur la pathologie des populations pléistocènes. Cette jeune femme adulte présente une troisième molaire supérieure droite incluse, une parodontite généralisée, de larges lacunes osseuses rétromolaires, deux dents surnuméraires au niveau des molaires du maxillaire droit et des traces d'os néoformé sur les branches mandibulaires et les faces postérieures des maxillaires. Pataud 1 rejoint ainsi l'ensemble important du sujets pléistocènes présentant des anomalies congénitales ou développementales parfois associées (et c'est le cas pour Pataud 1) à des atteintes secondaires. L'inclusion des $\mathrm{M}^{3}$ et les dents surnuméraires sont connues pour quelques autres sujets du Paléolithique supérieur moyen, et les parodontites de stade léger ou modéré sont fréquentes. Toutefois, une résorption alvéolaire aussi marquée chez un sujet jeune est rare, et l'inflammation secondaire (potentiellement septicémie) qui a entraîné la production d'os nouveau et qui peut avoir causé la mort du sujet est inconnue pour cet échantillon.

Mots clés Dent incluse · Dent surnuméraire · Parodontite · Septicémie

\section{Introduction}

Paleobiological analyses of Pleistocene human remains have identified a number of developmental abnormalities among them, giving the impression of an elevated level of such variants, which may be the consequence of pre- and/or post-natal stress or genetic variants (see [1] and references therein). It is 
unclear to what extent each of these developmental abnormalities impaired the functioning of the individual involved, although at least some of them remained physically active throughout their lives [e.g., 2-6]. In addition, several Pleistocene individuals (Dolní Věstonice 15, Tianyuan 1, Sunghir 3, Qafzeh 12, Romito 2, El Sidrón adult-2) appear to have sustained lesions, directly or indirectly, as a consequence of their primary abnormalities [4,5,7-10]. These Pleistocene human paleopathological cases raise questions regarding the levels of developmental stress, inbreeding, social support, and (in the Late Pleistocene) differential mortuary treatment of the afflicted individuals $[1,7,11]$. They therefore provide indirect reflections of the behavioral and adaptive patterns of these Pleistocene humans.

In this context, it is important to provide detailed assessments of Pleistocene individuals with developmental abnormalities. The late Mid-Upper Paleolithic skeleton from the Abri Pataud, Pataud 1 (P1) [12-14], exhibits a suite of dental developmental anomalies and lesions. Some of these were described by Legoux $[15,16]$. However, additional human remains from the Abri Pataud (especially of P1), reassignment of skeletal remains by individual, and a more holistic assessment of the P1 partial skeleton [13] provides further insights into its anomalies (and possible cause of death).

\section{Materials and methods}

Originally described by Billy [12] and Legoux [15-17], the $\mathrm{P} 1$ skeleton is now known to retain the cranium and mandible with all of the teeth except two lower incisors, 23 vertebrae, 15 ribs, a clavicle, a partial humerus, 42 hand bones, portions of both coxal bones, one femur, both patellae, and 33 pedal remains [13]. P1 represents the remains of a young adult female [14]. The sex assessment done on the left coxal bone [14] is supported by the small mastoid processes and relatively gracile cranium (in an Upper Paleolithic context) (Fig. 1). The spheno-occipital synchondrosis is partially fused, as is the proximal clavicular epiphysis, but all of the teeth (including the M3s) are fully formed with closed-root apices. The auricular surface retains clear transverse striations. Combined, these indicators suggest that this individual died at some point during the third decade of life, most likely in her early 20s [14].

The $\mathrm{P} 1$ skeleton is associated with five other individuals, two adults (P3 and P5) represented by upper limb remains, two infants (P2 and P4), and a juvenile (P6) [14]. They all derive from Level 2 of the Abri Pataud, Les Eyziesde-Tayac/Sireuil, Dordogne, France $\left(44^{\circ} 56^{\prime} 13^{\prime \prime} \mathrm{N}, 1^{\circ} 0^{\prime}\right.$ 47" E), excavated by H.L. Movius Jr. between 1958 and 1964 [18], and by R. Nespoulet and L. Chiotti from 2005 to 2009 [19]. Attributed to the "proto-Magdalenian" or Final Gravettian, Level 2 dates to 28,000-26,000 cal BP
[20]. As a result of the recent excavations, it has been possible to add to the sample of Level 2 human remains substantially, re-sort them by individual, and to draw inferences with regard to the associated mortuary behavior at the Abri Pataud $[13,14]$. As a result, the P1 skeleton is substantially more complete than originally described, thereby rendering the inventories of the human remains from Petit-Maire et al. [21] and Billy [12] incomplete and partially inaccurate.

Of primary concern, here are the dental abnormalities and associated facial skeletal lesions of $\mathrm{P} 1$. The remainder of her preserved skeletal remains is free of pathological lesions. The bones, and especially the alveolar processes, are exceptionally well-preserved for the Late Pleistocene (Figs. 1 and 2). The specimen was examined visually and using a $10 \times$ lens. The cranium of P1 was also investigated using $\mu \mathrm{CT}$ scans provided by the Muséum national d'Histoire naturelle. Dental wear was recorded following Smith [22] and Lovejoy [23]. Periodontal disease was recorded following Kerr [24,25] and Ogden [26].

\section{Results}

\section{The Pataud 1 dentition}

There is moderate occlusal wear on all of the teeth apart from the third molars (Figs 1-6). There is exposure of cuspal dentine on all first molars, premolars, canines and incisors (Smith stage 4; Lovejoy phase D). The wear is slightly greater on the left side. The crowns of all of the third molars are fully erupted from the alveoli, with the occlusal surfaces of the lower molars erupted to the level of the occlusal plane. The left $\mathrm{M}^{3}$ is within $1 \mathrm{~mm}$ of occlusal contact with the $\mathrm{M}_{3}$, but the right $\mathrm{M}^{3}$ is $4-5 \mathrm{~mm}$ out of contact, as a result of its mesio-angular impaction against the distal bulge above the amelo-cemental junction of the second molar (Figs 2, 3).

The crown morphology of the P1 dentition is largely unexceptional in an Upper Paleolithic context, with occlusal complexity present primarily on the M3s. However, the mandibular molars are progressively larger distally $\left(\mathrm{M}_{1}<\right.$ $\mathrm{M}_{2}<\mathrm{M}_{3}$ ), and the $\mathrm{M}_{3}$ s (length $\times$ breadth of 153.3 and $150.3 \mathrm{~mm}^{2}$ ) are among the largest known for the Early and Mid-Upper Paleolithic. They are matched only by Předmostí $3\left(152.3 \mathrm{~mm}^{2}\right)$ and exceeded only by Oase $1\left(170.5 \mathrm{~mm}^{2}\right)$ $[27,28]$.

\section{General oral pathology and dental abnormalities}

There is residual evidence of widespread covering of dental plaque and calculus on the buccal and lingual surfaces of all teeth. The root surfaces are vertically exposed by $2-5 \mathrm{~mm}$, indicating some resorption of the alveolar margin, especially in the context of the minimal occlusal wear (and hence the root 


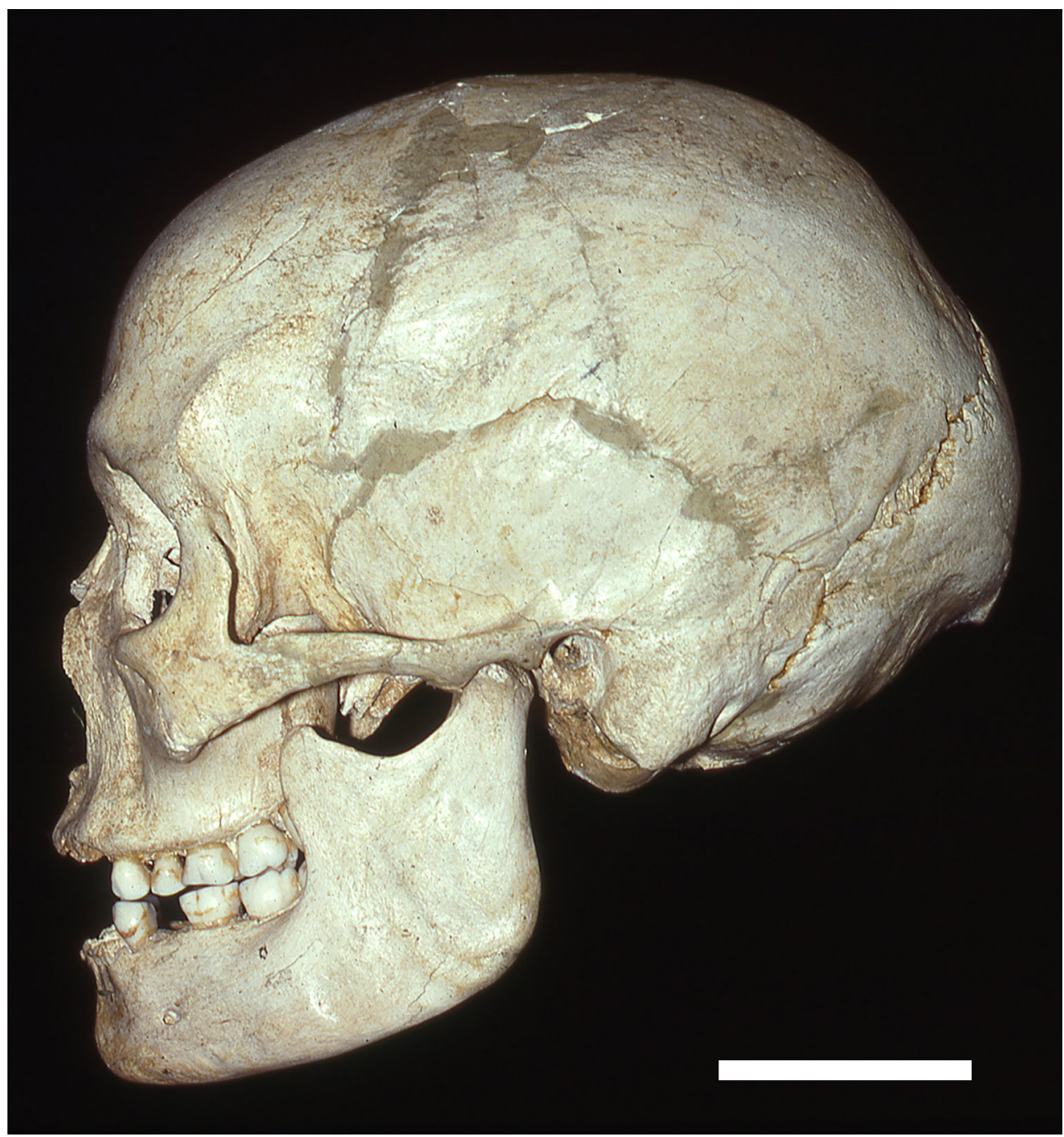

Fig. 1 Left lateral view of the P1 skull without the anterior teeth recovered recently [13]. Scale: $5 \mathrm{~cm} /$ Vue latérale gauche du crâne de P1 sans les dents antérieures découvertes récemment [13]. Échelle : $5 \mathrm{~cm}$

exposure is unlikely to be due to supraeruption). The developmentally original bony margin survives only on some lingual aspects; it has completely disappeared on the buccal and labial alveoli of all the teeth, where it is replaced by a level, rolled and porous margin with flattening of the interdental septae (Fig. 6). There are also large retromolar voids distal of the $\mathrm{M}_{3} \mathrm{~s}$ (Figs 4, 7a). There are also two supernumerary teeth of simple conical form buccal to the right $\mathrm{M}^{2}$ (Figs 2, 5). One of them has its root fused to the buccal $\mathrm{M}^{2}$ root, and the other was separate. They have single but bifurcated roots, and both were apparently erupted at the time of death.

\section{Secondary abnormalities}

There are large plaques of new bone deposition on the mandible and maxillae (Figs 5, 7). In the mandibular retromolar areas, there are isolated elevated plaques of unconsolidated new bone with a woven appearance (Fig. 7a). On the lingual aspects of both rami, from the mandibular foramen to the mandibular notch, there are large areas of sclerotic new bone formation. The surface texture is similar to normal bone but with multiple small foramina (Fig. 7). An area of sclerotic new bone formation is also present on the infratemporal surfaces of both maxillae. On both sides, these areas surround the apertures of what appears to be alveolar neurovascular canals (Fig. 5).

\section{Discussion}

\section{Supernumerary teeth}

The two additional teeth represent separate dental elements, even though the root of the one immediately adjacent to the 


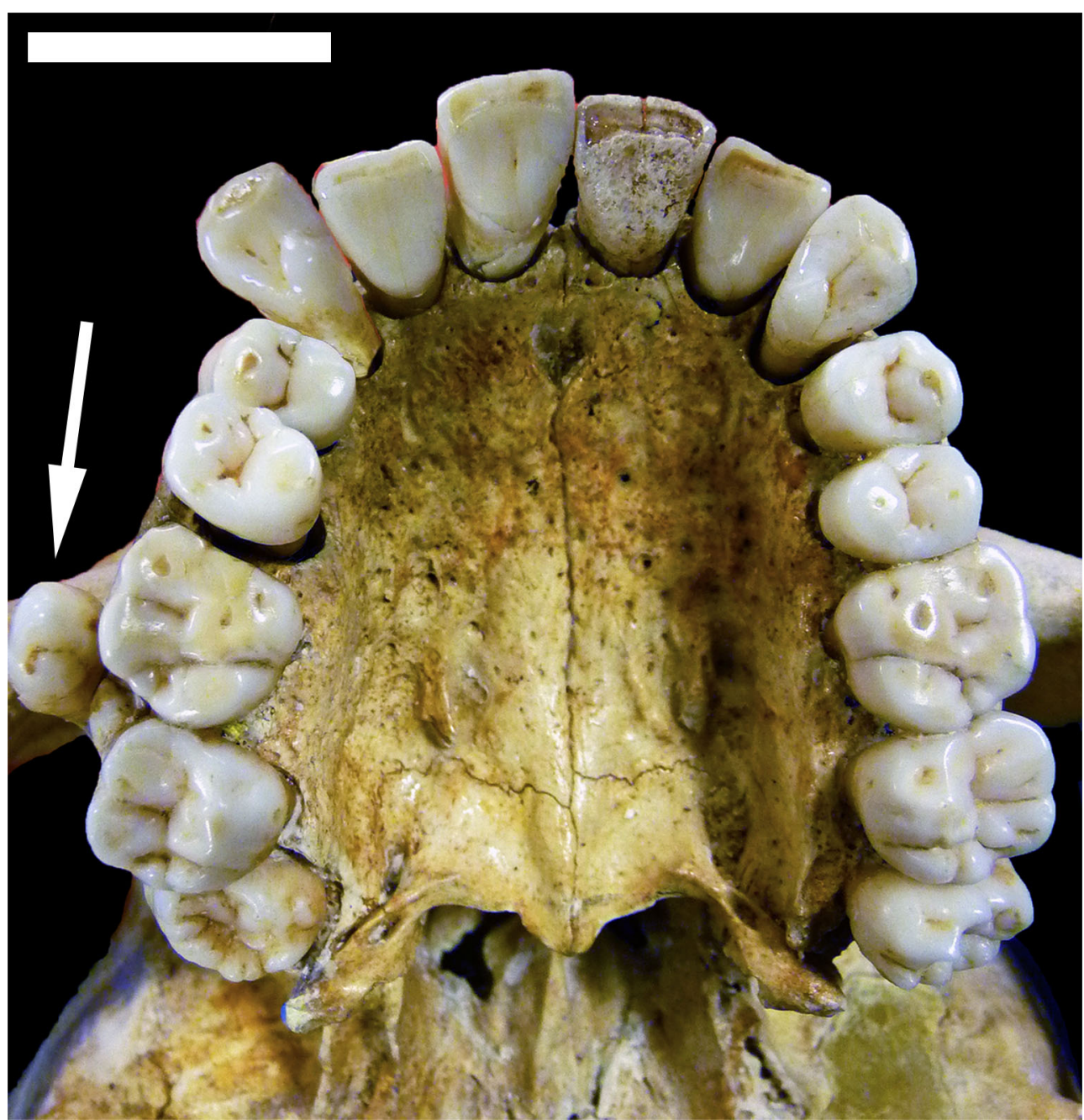

Fig. 2 Occlusal view of the P1 maxillary dental arcade (the right canine has been added digitally because the broken/glued root does not fit in the socket). Note the supernumerary teeth (arrow), and the large third molars. Scale: $2 \mathrm{~cm} /$ Vue occlusale de l'arcade dentaire maxillaire de P1 (la canine droite a été ajoutée par photomontage, car sa racine cassée et recollée ne rentre plus dans son alvéole). Les dents surnuméraires (flèche) et les troisièmes molaires larges sont notables. Échelle : $2 \mathrm{~cm}$.

$\mathrm{M}^{2}$ is fused to that tooth. It does not represent a parastyle, a supplemental cusp adjacent to the paracone, given its independent pulp chamber. The two supplemental conical teeth are therefore best viewed as supernumerary teeth with secondary fusion of the more lingual one to the $\mathrm{M}^{2}$ [29]. Given their position adjacent to the buccal $\mathrm{M}^{2}$ and the $\mathrm{M}^{1} / \mathrm{M}^{2}$ septum, they are best classified as paramolars [30].

Supernumerary teeth in the molar region (paramolars) are among the least common of such supplemental teeth [3135 ], occurring in $0.3 \%-0.8 \%$ of recent clinical samples. They occur mostly distal to the M3s (distomolars), and small ones adjacent to the regular molars are noted primarily as individual cases [36,37]. In two recent human samples, paramolars had frequencies of $0.06 \%$ and $\approx 0.2 \%[35,36]$. They may be lingual or buccal and can be maxillary or mandibular; mandibular versus maxillary predominance is vari- ably reported [30,37 versus 38,39$]$. Paramolar crowns can be simple conical shapes or may be more molariform [40]. They are rarely bilateral $[37,41]$, but the double unilateral ones of Pataud 1 appear to be unreported. Paramolars are usually located adjacent to the $\mathrm{M}^{2} / \mathrm{M}^{3}$, and rarely occur at the $\mathrm{M}^{1} / \mathrm{M}^{2}$ [36]. As with supernumerary teeth in general $[32,35]$, they are more common in males. In this context, the double maxillary $\mathrm{M}^{2}$ to $\mathrm{M}^{1} / \mathrm{M}^{2}$ paramolars in the Pataud 1 female are exceptional. The already low probability of finding a paramolar in an isolated Pleistocene specimen, even with the relatively abundant sample of Upper Paleolithic remains, would be further reduced by it being double and in a female.

Supernumerary teeth may be clinically silent or the cause of complications, such as disturbed tooth eruption, tooth rotation, cystic formation, crowding, spacing or diastemata 


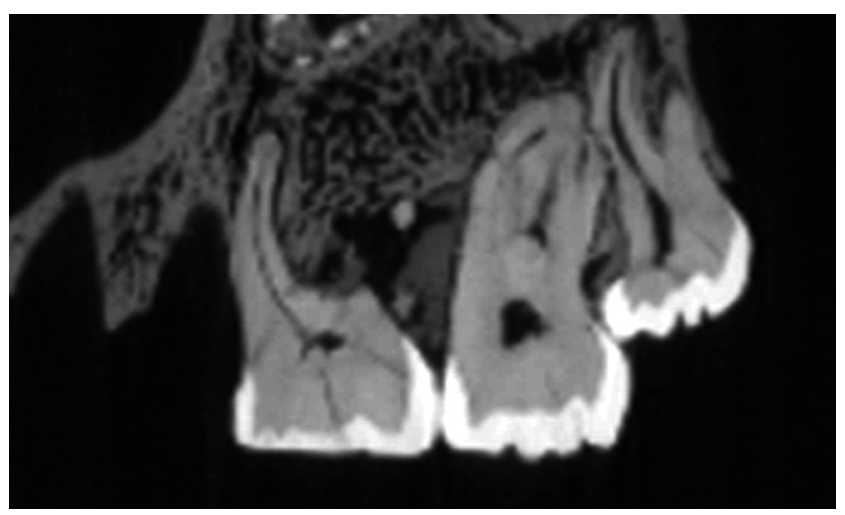

Fig. 3 Lateral view of a parasagittal section through the CT data at the level of the right upper molars, showing the impaction of the third molar against the second molar / Vue latérale d'une section parasagittale des données scanners au niveau des molaires supérieures droites, illustrant l'impaction de la troisième molaire contre la deuxième

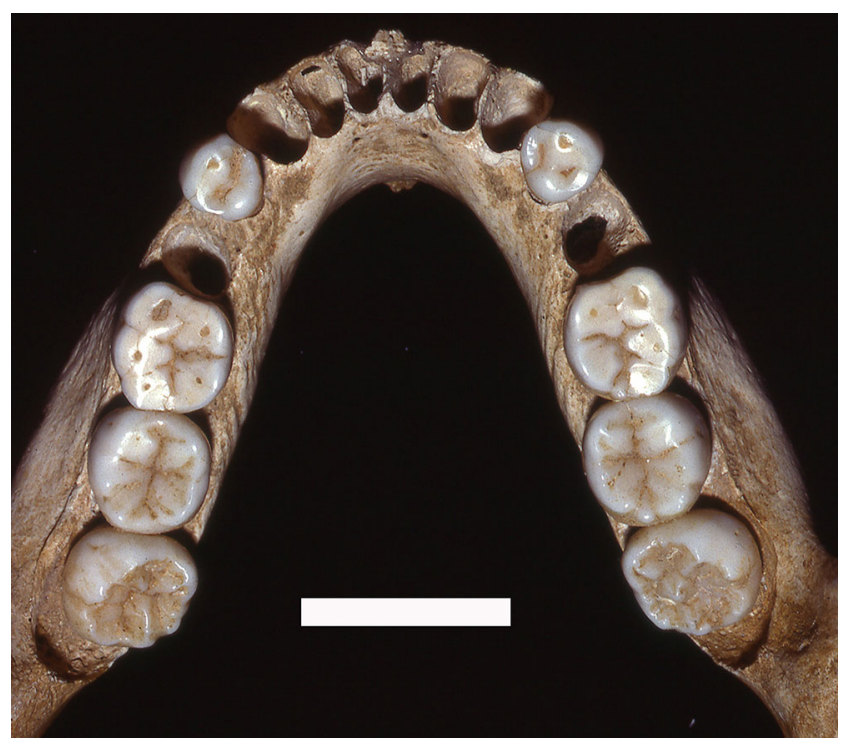

Fig. 4 Occlusal view of the P1 mandible, showing the progressively larger distal molars, the occlusal complexity of the $\mathrm{M}_{3} \mathrm{~s}$, and the retromolar voids. The recently discovered mesial teeth are not included. Scale: $2 \mathrm{~cm} /$ Vue occlusale de la mandibule de P1, montrant l'augmentation distale progressive des dimensions des molaires, la complexité morphologiques des troisièmes molaires et les lacunes osseuses au niveau des espaces rétromolaires. Les dents antérieures récemment découvertes ne sont pas incluses. Échelle : $2 \mathrm{~cm}$

of normal teeth [31,36,42-46]. Most supernumerary teeth are idiopathic, but they also occur in genetic syndromes, the two most commonly cited ones being cleidocranial dysplasia and familial adenomatous polyposis (FAP) [47]. Supernumerary teeth are reported in other conditions, such as Nance-Horan, trichorhinophalangeal, Opitz $\mathrm{BBB} / \mathrm{G}$, Rubinstein-Taybi, oculofaciocardiodental, and Robinow syndromes [47]. All of these conditions usually imply skeletal manifestations [47-49] not seen in P1. Thus, it is best to consider the supernumerary teeth in $\mathrm{P} 1$ as idiopathic.

In the Mid-Upper Paleolithic, there are at least two other cases of dental congenital developmental abnormalities. The Pataud 6 (P6) juvenile exhibits a vertically inverted development of the right $\mathrm{P}^{4}[15,16]$; its position cannot be due to postmortem displacement in the crypt, as the tooth germ is firmly maintained in its position by the root of the right $\mathrm{dm}^{2}$. Such dental developmental inversions are very rare [50]. The Dolní Věstonice 15 mandible has an unerupted mandibular supernumerary tooth, and the isolated Dolní Věstonice 33 and Pavlov 21 teeth may have been supernumeraries [51,52].

\section{Dental impaction}

The $\mathrm{P} 1$ dentition exhibits impaction of the right $\mathrm{M}^{3}$, leading to its incomplete eruption by the time of death. Dental crowding is known in the Mid-Upper Paleolithic [7], but there are only three cases of third molar impaction (Dolní Věstonice 3 and 15, and Cro-Magnon 4258), all of which involve the mandibular third molars $[52,53]$.

\section{Periodontal disease}

Periodontitis is the result of the accumulation of bacterial plaque at the gum margins leading to inflammation and destruction of the periodontal tissues that anchor the tooth. It is characterized by the presence of inflammation at the marginal gingivae, together with loss of attachment, which results in the formation of a periodontal pocket (a pathologically-deepened gingival crevice, forming a cylindrical cavity around the root, extending toward the apex). Chronic periodontitis is usually painless. However, the tissue destruction seen in periodontitis is progressive and irreversible. Bone loss is probably not the result of any specific destructive factor, but may be more dependent on the balance between destructive bacterial factors and the level of host response [54,55].

The modern dentistry definition of periodontal disease (a distance of $>2 \mathrm{~mm}$ between the amelo-cemental junction and the alveolar crest) is problematic in fossils because alveolar crests preserve poorly and it assumes minimal dental wear or continuous eruption due to a lack of opposing dentition [26]. However, in the P1 remains, the minor dental wear, the marked resorption of the alveolar margin, and its appearance (rolled and porous) exclude taphonomic processes and compensatory/continuous eruption, thus indicating a diagnosis of mild to moderate periodontitis [24-26]. The overall 




Fig. 5 Posterolateral view of the P1 right maxilla showing the form and position of the supernumerary tooth still in place, and the socket of the second supernumerary tooth, plus the second (more buccal) supernumerary tooth separated from its alveolus. Note the remains of calculus on the buccal surfaces of the teeth and the area of sclerotic new bone formation present on the infratemporal surface, surrounding the aperture of the alveolar canal (arrow). Scale: $2 \mathrm{~cm} /$ Vue postérolatérale du maxillaire droit de P1, avec la dent surnuméraire encore en place et la localisation de la deuxième dent surnuméraire, les restes de tartre sur les surfaces buccales des dents et la zone d'os néoformé autour de l'ouverture du canal alvéolaire (flèche). Échelle : $2 \mathrm{~cm}$

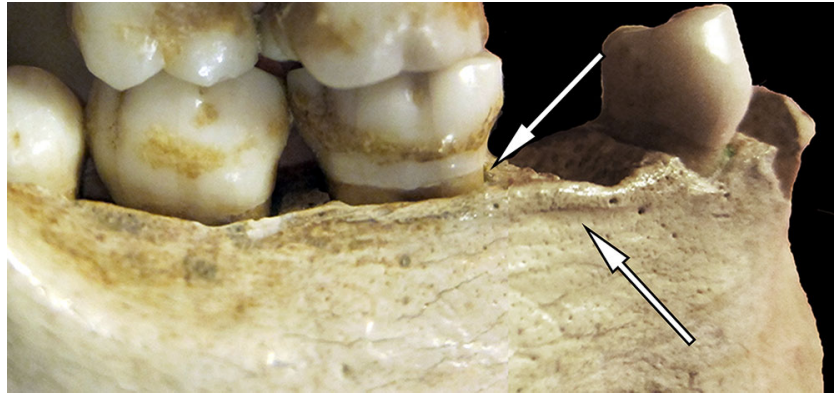

Fig. 6 View of the P1 right mandible showing the resorption of the margin of the alveolus with flattening of the interdental septae / Vue latérale droite de la mandibule de P1 montrant la résorption alvéolaire et l'aplatissement des septums interalvéolaires

pattern in P1 is not exceptional, except for its extent in an adult who died in the early third decade of life.

Several cases of periodontitis (juvenile or aggressive types) occurring with the presence of supernumerary teeth have been reported [56-62]. The biological relationship between the two phenomena is debated [59]. To distinguish an aggressive periodontitis in quiescent phase from a chronic type in archeological material appears challenging [63], and a relationship between the supernumerary teeth and periodontitis cannot be ruled out for P1.

\section{Pataud 1 new bone growth}

Legoux hypothesized that the oral health of P1 was sufficiently poor that she may have died from septicemia $[15,16]$. However, even though periodontitis is associated with an increase in mortality risk [64], it is relatively common in living populations [55] and present in half $(n=36)$ of the Early/Mid-Upper Paleolithic adolescents and adults [53]. Thus, the periodontitis of P1 per se does not appear as a special case for the Late Pleistocene. Yet, the large plaques of new bone deposition on the mandible and maxillae, not mentioned by Legoux, indicate a more advanced condition (it is worth mentioning that a similar - though more severe - case has been reported by Anderson [65]).

In the retromolar areas, the woven appearance of the new bone formation indicates that the periosteal reaction was active at the time of death, whereas in the other affected areas the surface texture is more similar to normal bone but hypervascularized, indicating inactive or slowly progressing lesions [66]. We can discard the hypothesis that these 


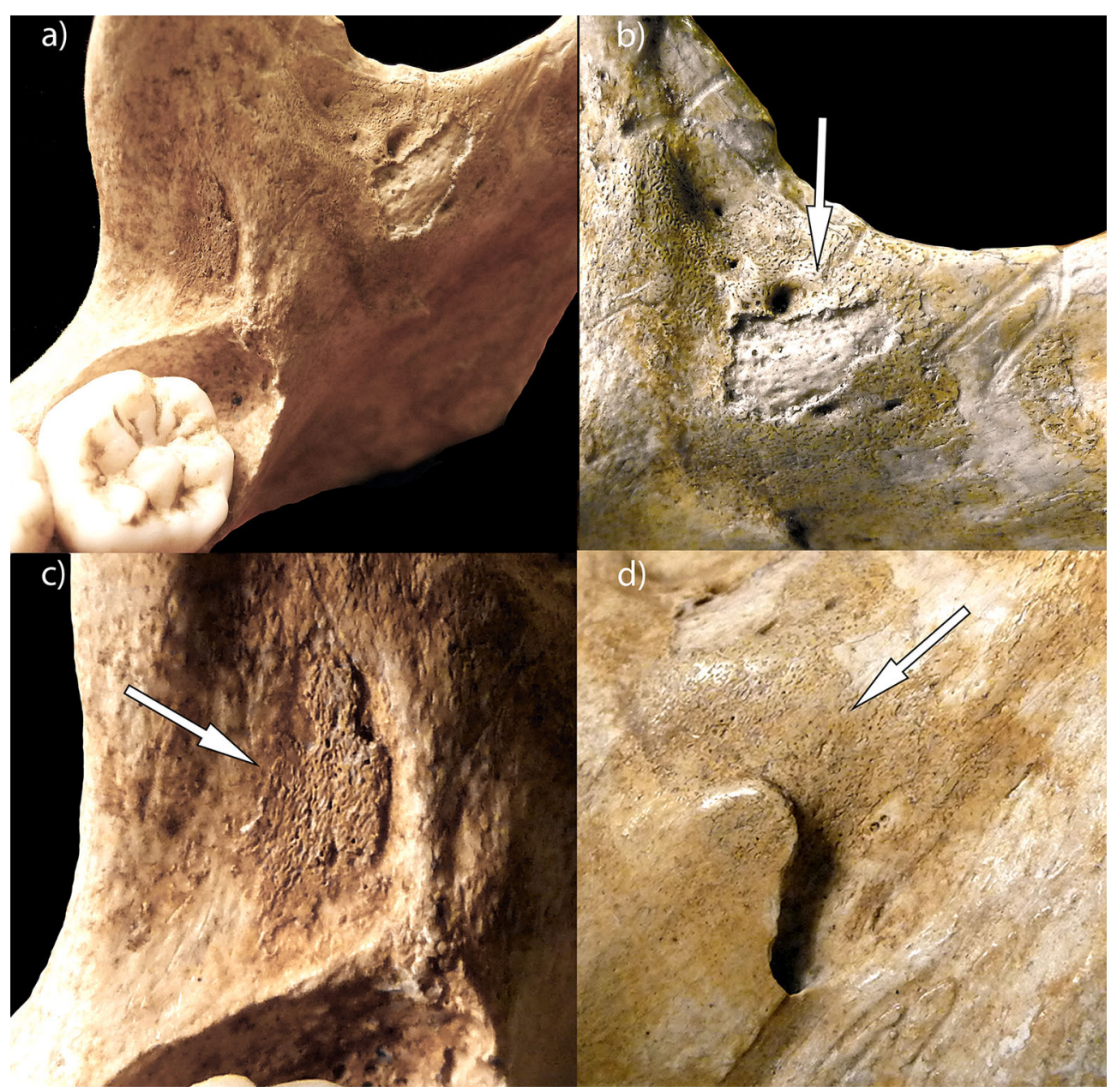

Fig. 7 Views of the new bone plaque formation on the right side of the P1 mandible. Note the isolated elevated plaque of unconsolidated new bone with a woven appearance in the retromolar area (arrow in C) and the area of sclerotic new bone formation on the lingual aspect of the ramus (arrows in $\mathrm{B}$ and D) / Vue de la face interne droite de la mandibule de P1. On note une plage isolée surélevée d'os nouveau (aspect tissé) dans l'espace rétromalaire (C, flèche) et une plage d'os néoformé plus ancienne sur la face interne de la branche montante (B et $D$, flèches)

changes are related to the growing process; periosteal reactions are relatively common in juveniles, but they are seen in infants [66], not in individuals in early adulthood. We can also discard a taphonomic origin for these changes as they indicate both production of new bone and hypervascularization.

The lesions clearly visible in $\mathrm{P} 1$ are osteological evidence of long-standing and widespread inflammation of the mucosa and periosteum of the anterior oro-pharynx, still active at the time of death. Moreover, the area of sclerotic new bone formation surrounding the aperture of the alveolar neurovascular canal of both sides is most readily explained as the retrograde spread of infection from a tooth or the maxillary sinus along these canals.

Periosteal reactions should be interpreted with caution, as its etiology appears to have minimal influence over its eventual macroscopic and radiological appearance [67]. How- ever, in this well-preserved specimen, it is possible to identify the most probable origin of these plaques of new bone deposition, and to formulate a hypothesis regarding the death of the individual. Soft-tissue swelling and tooth impaction, worsened by the supernumeraries on the right, allowed major food and plaque stagnation, would have produced an acute pericoronitis of the mucosa with inflammation of the underlying periosteum. The pericoronitis would have led to a massive swelling of the mucosa, probably compounded with trismus caused by spasm of the medial pterygoid muscles $[68,69]$. This would have worsened the condition, making any form of oral hygiene impossible. Eventually this would have led to local suppurative complications (peritonsillar abscess or cellulitis), which may have caused the premature death of this individual through a combination of respiratory obstruction and septicemia. Although death from an oral infection is currently extremely rare, even 
simple pericoronitis around erupting teeth could develop into a deadly infection before the advent of antibiotics [70]. Thus, even if the hypothesis of P1 dying by septicemia is not testable, our assessment indicates that it appears to be a strong possibility.

\section{Conclusion}

The young adult female from the Abri Pataud joins a growing list of Pleistocene human remains with developmental abnormalities, in this case the maxillary supernumerary teeth. In combination with the impacted right $\mathrm{M}^{3}$ and a generally high level of periodontal inflammation for someone early in the third decade, this individual experienced substantial new bone formation on the maxillary and mandibular areas adjacent to the posterior dentition. As such, it adds to the growing list of Pleistocene human remains with either rare or exceptional (undiagnozable) developmental conditions $[1,7,11,71]$. The young adult female from the Abri Pataud adds another unusual individual to this pattern.

Acknowledgments A. Fort, V. Laborde, and L. Huet (Muséum national d'Histoire naturelle, Musée de l'Homme) have allowed access to the material and helped during their study. D. Henry-Gambier (CNRS, PACEA), in-charge of the study of the human remains from the Abri Pataud, and R. Nespoulet and L. Chiotti (MNHN), in-charge of the new excavations, furnished support throughout. We are grateful to all of them. We also thank the two anonymous reviewers for their useful comments.

Conflict of interest: The authors do not have any conflict of interest to declare.

\section{Reference}

1. Wu XJ, Xing S, Trinkaus E (2013) An enlarged parietal foramen in the late archaic Xujiayao 11 neurocranium from Northern China, and rare anomalies among Pleistocene Homo. PLoS ONE 8:e59587 doi: 10.1371/journal.pone.0059587

2. Villotte S, Samsel M, Sparacello V (2017) The paleobiology of two adult skeletons from Baousso da Torre (Bausu da Ture) (Liguria, Italy): Implications for Gravettian lifestyle. C R Palevol 16:462-73

3. Crevecœur I, Villotte S (2006) Atteintes pathologiques de Nazlet Khater 2 et activité minière au début du Paléolithique supérieur en Égypte. BMSAP 18:165-75

4. Trinkaus E, Formicola V, Svoboda J, et al (2001) Dolní Věstonice 15: Pathology and persistance in the Pavlovian. J Archaeol Sci 28:1291-308

5. Shang H, Trinkaus E (2010) The early modern human from Tianyuan Cave, China. Texas A\&M University Press, College Station, $272 \mathrm{p}$
6. Cowgill LW, Mednikova MB, Buzhilova AP, et al (2015) The Sunghir 3 Upper Paleolithic juvenile: pathology versus persistence in the Paleolithic. Int J Osteoarchaeol 25:176-87

7. Trinkaus E, Buzhilova AP, Mednikova MB, et al (2014) The people of Sunghir. Burials, bodies, and behavior in the earlier Upper Paleolithic. Oxford University Press, New York, $368 \mathrm{p}$

8. Tillier A-M, Arensburg B, Duday H, et al (2001) An early case of hydrocephalus: The middle Paleolithic Qafzeh 12 child (Israel). Am J Phys Anthropol 114:166-70

9. Tilley L (2015) Accommodating difference in the prehistoric past: Revisiting the case of Romito 2 from a bioarchaeology of care perspective. Int J Paleopathol 8:64-74

10. Dean M, Rosas A, Estalrrich A, et al (2013) Longstanding dental pathology in Neandertals from El Sidrón (Asturias, Spain) with a probable familial basis. J Hum Evol 64:678-86

11. Formicola V (2007) From the Sunghir children to the Romito dwarf: Aspects of the upper Paleolithic funerary landscape. Curr Anthropol 48:446-53

12. Billy G (1975) Étude anthropologique des restes humains de l'Abri Pataud, in Excavation of the Abri Pataud. Les Eyzies (Dordogne): HL Movius Jr, Editor. Am Sch Prehist Res Bull 30:201-61

13. Villotte S, Chiotti L, Nespoulet R, et al (2015) Étude anthropologique des vestiges humains récemment découverts issus de la couche 2 de l'abri Pataud (Les Eyzies-de-Tayac-Sireuil, Dordogne, France). BMSAP 27:158-88

14. Henry-Gambier D, Villotte S, Beauval C, et al (2013) Les vestiges humains : un assemblage original. In: Nespoulet R, Chiotti L, Henry-Gambier D (eds) Le Gravettien final de l'abri Pataud (Dordogne, France). Fouilles et études 2005-2009. Archaeopress, BAR Int Ser, 2458, Oxford, pp 135-77

15. Legoux P (1972) Étude odontologique des restes humains périgordiens et protomagdaléniens de l'Abri Pataud (Dordogne). BMSAP 9:293-330

16. Legoux P (1974) Étude odontologique des restes humains périgordiens et protomagdaléniens de l'Abri Pataud (Dordogne) (seconde partie). BMSAP 1:45-84

17. Legoux P (1975) Présentation des dents des restes humains de l'Abri Pataud, In Excavation of the Abri Pataud. Les Eyzies (Dordogne): Movius HL Jr, (ed). Am Sch Prehist Res Bull 30:262-304

18. Movius Jr HL (ed) (1975) Excavation of the Abri Pataud, Les Eyzies (Dordogne). Am Sch Prehist Res Bull 30:1-305

19. Chiotti L, Nespoulet R, Henry-Gambier D (2013) Une nouvelle fouille à l'abri Pataud. In: Nespoulet R, Chiotti L, HenryGambier D (eds) Le Gravettien final de l'abri Pataud (Dordogne, France). Fouilles et études 2005-2009. Archaeopress, BAR International Series, 2458, Oxford, pp 13-21

20. Henry-Gambier D, Nespoulet R, Chiotti L, et al (2013) Datations. In: Nespoulet R, Chiotti L, Henry-Gambier D (eds) Le Gravettien final de l'abri Pataud (Dordogne, France). Fouilles et études 20052009. Archaeopress, BAR International Series, 2458, Oxford, pp 43-50

21. Petit-Maire N, Ferembach D, Bouvier JM, et al (1971) France. Oakley KP, Campbell BG, Molleson TI (eds) Catalogue of Fossil Hominids II: Europe. British Museum (Natural History), London, pp 71-187

22. Smith BH (1984) Patterns of molar wear in hunter-gatherers and agriculturalists. Am J Phys Anthropol 63:39-56

23. Lovejoy CO (1985) Dental wear in the Libben population: Its functional pattern and role in the determination of adult skeletal age at death. Am J Phys Anthropol 68:47-56

24. Kerr N (1998) The prevalence and natural history of periodontal disease in Britain from prehistoric to modern times. Br Den J 185:527-35

25. Kerr N (1988) A method of assessing periodontal status in archaeologically derived skeletal material. J Paleopathol 2:67-78 
26. Ogden AR (2008) Advances in the paleopathology of teeth and jaws. S Mays, R Pinhasi (eds) Advances in Human Paleopathology. Wiley, Chichester, pp 283-307

27. Matiegka J (1934) Homo předmostensis, fosilní člověk z Předmostí na Moravě. T1. Nákladem České akademie věd a umění, Prague, $145 \mathrm{p}$

28. Trinkaus E, Bailey SE, Rougier H (2013) The dental and alveolar remains of Oase 1 and 2. Trinkaus E, Constantin S, Zilhão J (eds) Life and death at the Peștera cu Oase. A setting for modern human emergence in Europe. Oxford University Press, New York, pp 348-74

29. Duncan WK, Helpin ML (1987) Bilateral fusion and gemination: A literature analysis and case report. Oral Surg Oral Med Oral Pathol 64:82-7

30. Nayak G, Shetty S, Singh I, Pitalia D (2012) Paramolar — a supernumerary molar: a case report. Dental Res J (Isfahan) 9:797-803

31. Lavelle CLB, Moore WJ (1973) The incidence of agenesis and polygenesis in the primate dentition. Am J Phys Anthropol 38:671-80

32. Scheiner MA, Sampson WJ (1997) Supernumerary teeth: A review of the literature and four case reports. Australian Dental J 42:160-5

33. Rajab LD, Hamdan MAM (2002) Supernumerary teeth: Review of the literature and a survey of 152 cases. Int J Paediat Dentistry 12:244-54

34. Leco MI, Martín JF, Martínez JM (2007) An observational study of the frequency of supernumerary teeth in a population of 2000 patients. Med Oral Patol Oral Cirugia Bucal 12:e134-8

35. Celikoglu M, Kamak H, Oktay H (2010) Prevalence and characteristics of supernumerary teeth in a non-syndrome Turkish population: Associated pathologies and proposed treatment. Med Oral Patol Oral Cirugia Bucal 15:e575-8

36. Grimanis G, Kyriakides A, Spyropoulos N (1991) A survey on supernumerary molars. Quintessence Int 22:989-95

37. Nagaveni NB, Umashankara KV, Radhika NB, Praveen RP, et al (2010) Maxillary paramolar: report of a case and literature review. Arch Orofacial Sci 5:24-8

38. Timocin N, Yalcin S, Ozgen M, Tanyeri H (1994) Supernumerary molars and paramolars. J Nihon Univ Sch Dentist 36:145-50

39. Parolia A, Kundabala M, Dahal M, Mohan M, et al (2011) Management of supernumerary teeth. J Conserv Dentist 14:221-4

40. Loh FC, Yeo JF (1993) Paramolar with bifid crown. Oral Surg Oral Med Oral Pathol Oral Radiol 76:257-8

41. Dhull KS, Dhull RS, Panda S, Acharya S, et al (2014) Bilateral mandibular paramolars. Int J Clin Pediatric Dentist 7:40-2

42. Rajab LD, Hamdan MAM (2002) Supernumerary teeth: review of the literature and a survey of 152 cases. Int J Paediatric Dentist 12:244-54

43. Proff P, Fanghänel J, Allegrini S, et al (2006) Problems of supernumerary teeth, hyperdontia or dentes supernumerarii. Ann Anat 188:163-9

44. Anthonappa R, King N, Rabie A (2013) Aetiology of supernumerary teeth: a literature review. Eur Arch Paediatric Dentist $14: 279-88$

45. Martínez-González J, Cortés-Bretón Brinkmann J, Calvo-Guirado J, et al (2012) Clinical epidemiological analysis of 173 supernumerary molars. Acta Odontol Scand 70:398-404

46. Menardía-Pejuan V, Berini-Aytés L, Gay-Escoda C (2000) Supernumerary molars. A review of 53 cases. Bull Group Int Rech Sci Stomatol Odontol 42:101-5

47. Lubinsky M, Kantaputra PN (2016) Syndromes with supernumerary teeth. Am J Med Genet A 170:2611-16

48. Wijn MA, Keller JJ, Giardiello FM, et al (2007) Oral and maxillofacial manifestations of familial adenomatous polyposis. Oral Diseases 13:360-5
49. Cooper SC, Flaitz CM, Johnston DA, et al (2001) A natural history of cleidocranial dysplasia. Am J. Med Genet 104:1-6

50. Mohan S, Kankariya H, Fauzdar S (2012) Impacted inverted teeth with their possible treatment protocols. J Maxillofacial Oral Surg 11:455-7

51. Trinkaus E, Hillson SW, Franciscus RG, et al (2006) Skeletal and dental paleopathology. Trinkaus E, Svoboda J (eds) Early modern human evolution in Central Europe. The people of Dolní Věstonice and Pavlov. Oxford University Press, New York, pp 419-58

52. Hillson SW (2006). Dental morphology, proportions, and attrition. Trinkaus E, Svoboda J (eds) Early modern human evolution in Central Europe. The people of Dolní Věstonice and Pavlov. Oxford University Press, New York, pp 179-223

53. Lacy SA (2014) Oral Health and its Implications in Late Pleistocene Western Eurasian Humans. unpublished $\mathrm{PhD}$ thesis, Washington University in Saint Louis, p 243

54. Clarke NG, Carey SE (1985) Etiology of chronic periodontal disease: an alternative perspective. J Am Dent Assoc 110:689-91

55. Jenkins WM, Kinane DF (1989) The "high risk" group in periodontitis. Brit Dent J 167:168-71

56. Shanmugam M, Anitha V, Shivakumar V, et al (2013) A rare combination of aggressive periodontitis with multiple impacted supernumerary teeth. Chettinad Health City Med J 2:96-8

57. Salman A, Meethil A (2012). An unusual presentation of generalized aggressive periodontitis with multiple impacted supernumerary teeth. Eur J Dentist 6:335-9

58. Verma V, Goel A, Sabir M (2010). Supernumerary eumorphic mandibular incisor in association with aggressive periodontitis. $\mathrm{J}$ Indian Soc Periodontol 14:136-8

59. Açikgöz G, Açikgöz A, Keskiner İ, et al (2004) Aggressive periodontitis with supernumerary teeth: A Retrospective Study. J Periodontol 75:1458-60

60. Odell EW, Hughes FJ (1995) The possible association between localized juvenile periodontitis and supernumerary teeth. J Periodontol 66:449-51

61. Rubin M, Nevins A, Berg M, et al (1981) A comparison of identical twins in relation to three dental anomalies: multiple supernumerary teeth, juvenile periodontosis, and zero caries incidence. Oral Surg Oral Med Oral Pathol 52:391-4

62. Eley BM (1974) Periodontosis occurring with supernumerary molars. J Dentist 2:167-70

63. Tomczyk J, Turska-Szybka A, Zalewska M, et al (2017) Reliability of the assessment of periodontal disease in historical populations. Int J Osteoarchaeol 27:206-16

64. DeStefano F, Anda RF, Kahn HS, et al (1993) Dental disease and risk of coronary heart disease and mortality. BMJ 306:688-91

65. Anderson T (2004) An unusual medieval mandibular pathology. Arch Oral Biol 49:331-5

66. Weston DA (2012) Nonspecific infection in paleopathology: Interpreting periosteal reactions. Grauer AL (ed) A companion to paleopathology. Wiley, New York, pp 492-512

67. Weston DA (2008) Investigating the specificity of periosteal reactions in pathology museum specimens. Am J Phys Anthropol 137:48-59

68. Cawson RA, Odell EW (2002) Cawson's essentials of oral pathology and oral medicine (7th ed). Churchill Livingstone, Edinburgh $416 \mathrm{p}$.

69. Scully C (2008) Oral and maxillofacial medicine: The basis of diagnosis and treatment (2nd ed). Churchill Livingstone, Edinburgh, $448 \mathrm{p}$

70. Cox M (1996) Life and Death in Spitalfields 1700-1850. Council for British Archaeology, York, $150 \mathrm{p}$

71. Villotte S, Knüsel CJ, Mitchell PD, et al (2011) Probable carpometacarpal and tarsal coalition from Baousso da Torre Cave (Italy): Implications for burial selection during the Gravettian. J Hum Evol 61:117-20 